\title{
The Social Exclusion of the Elderly: A Mixed-Methods Study in Slovenia
}

\author{
MAŠA FILIPOVIČ HRAST, VALENTINA HLEBEC \\ and MATIC KAVČIČ* \\ University of Ljubljana
}

\begin{abstract}
The elderly are in many ways more vulnerable than other groups in society. To research the vulnerabilities of the elderly, this article works with the concept of social exclusion. It analyses social exclusion using a mixed-method model drawing on secondary quantitative data combined with in-depth interviews. The quantitative data were used to identify which areas of social exclusion particularly affect older people in Slovenia. The areas observed in the study were material deprivation, spatial exclusion, poor health and access to health care, housing exclusion and interpersonal exclusion, and the first three areas were identified as the most problematic and widespread. The strategies the elderly use to cope with social exclusion were analysed using qualitative data and the grounded theory approach. In all areas various coping strategies were observed that indicate that the elderly are actively trying to improve their situation. It also seems that similar strategies are employed in different areas of social exclusion, the most important of them being strategies based on individuals' capacities and social networks.
\end{abstract}

Keywords: social exclusion, mixed methods, coping strategies, secondary data, the elderly, Slovenia

Sociologický časopis/Czech Sociological Review, 2012, Vol. 48, No. 6: 1051-1074

\section{Introduction}

The whole of Europe is facing an intensive demographic change as a result of low fertility rates and the ageing of the population. This demographic change is having a profound impact on society, its welfare systems, intergenerational relations, family changes, and more. The quality of life in old age and the social inclusion of the elderly are becoming increasingly pressing issues as the elderly population swells. In this article we examine the social exclusion of the elderly. Social exclusion constitutes a mixture of multidimensional and mutually reinforcing processes of deprivation and involves a progressive dissociation from social milieus, resulting in the isolation of individuals and groups from the mainstream of the opportunities society has to offer [Vleminckx and Berghman 2001]. It is a concept

\footnotetext{
* Direct all correspondence to: Maša Filipovič Hrast, Faculty of Social Sciences, University of Ljubljana, Kardeljeva Ploščad 16, SI-1001 Ljubljana, Slovenia, e-mail: Masa.Filipovic@ fdv.uni-lj.si.
} 
which has become a central feature of research and policy debates, but remains under-explored in gerontological research [Scharf, Phillipson and Smith 2005: 77]. Our research is therefore in line with the growing focus on social exclusion in the gerontological literature [see Phillipson, Scharf and Smith 2005; Ogg 2005].

In the literature on social exclusion, certain population groups are found to be more at risk of this phenomenon, with the elderly often included among the most vulnerable [Mayes, Berghman and Salais 2001; Muffels and Fourage 2002]. When speaking of the greater vulnerability of the elderly, this of course does not encompass the group as a whole but generally pertains to specific subgroups of the elderly. Women, in particular widows, those living alone, those with a lower education, and the oldest old people are more excluded [see, e.g., Scharf, Phillipson and Smith 2005; Ogg 2005]. In addition, the elderly living in rural areas are particularly vulnerable [Scharf, Phillipson and Smith 2005; Trbanc 1996]. There is also a significant amount of literature on various areas of social exclusion and the quality of life of the elderly [Smith et al. 2004; Bajekal et al. 2004; Moriarty and Butt 2004; Ogg 2005; Scharf, Phillipson and Smith 2005]. These authors emphasise as the main problems poor health, poor social networks or poor access to health care, living in poor neighbourhoods and having poor access to basic services [see, e.g., Simms 2004; Siegrist 2000; Dalstra, Kunst and Mackenbach 2006; Scharf, Phillipson and Smith 2005].

However, most of this literature is concentrated on the 'old member states' of the European Union, while less is known about social exclusion or the vulnerability of the elderly in the countries of Central and Eastern Europe (CEE). Is social exclusion affecting the elderly in these countries after the transition in different ways? Are there specific problematic areas in this region that differ from the problem areas found elsewhere? In a comparison of twelve countries (still not including any post-socialist countries), Tsakloglou and Papadopoulos [2002], for example, showed that only in some countries did the elderly suffer from greater social exclusion (i.e. in southern European countries), while Ogg [2005], in one of the few studies that did look at post-socialist countries, found no significant differences in the social exclusion of the elderly between post-socialist countries and southern European countries.

We conducted research in one post-socialist country-Slovenia. Further, the approach taken in this article involves a combination of both quantitative and qualitative analyses of social exclusion, an approach not often found in the abovecited studies. We believe that, as a very complex concept, social exclusion needs to be studied with both quantitative and qualitative methods [see also Walker 2004; Scharf et al. 2003]. Qualitative approaches have not often been used to study the social exclusion of the elderly, although there are numerous qualitative studies of the 'vulnerabilities' of the elderly, poverty and coping strategies, and quality of life [e.g. Schroder-Butterfill and Marianti 2006; Monroe et al. 2007; Sherman 2006; Langille-Hope et al. 2010; Walker 2004], which are all concepts related to social exclusion. We believe that qualitative research of life histories, everyday life and 
coping strategies offers a good conceptual tool for a qualitative study of social exclusion. The first argument is the dynamic nature of the concept and the emphasis on the processes that lead to exclusion and the possibilities of escaping poverty and exclusion, something that is captured well by the actual coping strategies people employ in individual areas of social exclusion. The second reason is the presumption of the fluidity of barriers of exclusion, which, however, might be less evident for the elderly, as has been pointed out by Scharf, Phillipson and Smith [2005]. Therefore, coping strategies offer an insight into the 'depth' of exclusion and the potential fluidity of the barriers of exclusion, that is to say, of whether or not they can be overcome by the elderly themselves (through their coping mechanisms) and in what ways the welfare state plays a role in this. By coping strategies we are referring to the concept of coping developed in the 1970s by psychologists, who defined coping as 'constantly changing cognitive and behavioural efforts to manage specific external and/or internal demands that are appraised as taxing or exceeding the resources of the person' [Lazarus and Folkman 1984: 141]. Understanding coping capacities as the assets, relationships, behaviour, and mental activities with which people protect themselves from a bad outcome or recover from a crisis [adapted from Schroder-Butterfill and Marianti 2006], we define coping strategies as the different actions and forms of behaviour people engage in in response to the perception of a threat to them [Lazarus and Folkman 1984].

Secondary quantitative data are used in the explanatory (participant selection model) mixed methods study [Creswell and Plano 2007] to analyse social exclusion [see also Walker 2004], which is then combined with in-depth interviews and the grounded theory [GT] approach. We seek to answer the following research questions:

- Are the elderly excluded in Slovenia (as a CEE post-transition country) and are there specific aspects of social exclusion (and the coping strategies of the elderly) that can be linked to the post-transitional context?

- Which specific areas of social exclusion affect the largest proportions of people (quantitative secondary data will be used to answer this)?

- How do the elderly experience social exclusion and what strategies do they employ to cope with social exclusion (a qualitative approach and grounded theory are used to answer this)?

\section{Social exclusion—theoretical background}

Social exclusion is a complex concept that focuses on the vulnerability of individuals and groups in society. It is linked in origin and content with concepts such as poverty, capabilities, quality of life [see Muffels and Fourage 2001; Raveaud and Salais 2001; Sen 2000; Atkinson et al. 2002; Room 1995]. Social exclusion is understood as multidimensional, involving deprivation across a range of dimensions [Layte, Maitre and Whelan 2010: 5]. 
This wide view of social exclusion allows vulnerabilities to be observed in the broader sense, along with the processes that lead to or potentially enable people to overcome or cope with these vulnerabilities. It also allows us to observe the link between various dimensions of social exclusion. In addition, it implies observing the vulnerability of people and groups in several spheres of life. Based on the literature [Mayes, Berghman and Salais 2001; Muffels and Fourage 2002; Ogg 2005] and established research in this area (e.g. the European Survey on Income and Living Conditions and the European Quality of Life Survey), we can define the following important areas in which to observe social exclusion/inclusion: income and material deprivation, the labour market, access to (social) services, housing, education, health, the local environment, and interpersonal relations.

Life-course theorists have noted that how quality of life is defined changes over a person's life span [Beaumont and Keanely 2004: 756], which might also be true in the case of social exclusion. However, research into the quality of life of the elderly [see Smith et al. 2004] has shown that dimensions important for this group correspond to those defined above and therefore support our use of them. We also had pragmatic reasons for using the established dimensions as we had to work within the limits of available secondary survey data.

\section{The Slovenian context}

In 2008 the share of people aged 65 and over in Slovenia was 15.3\%, somewhat below the EU-27 average of 16.8\%. Even though the data do not rank Slovenia alongside European countries with the largest share of the elderly, the country's old-age dependency ratio is among the highest in the EU and will remain so over the next 50 years. The old-age dependency ratio was $22.9 \%$ in 2008 and is expected to leap to $62.2 \%$ by 2060 [European Commission 2008]. In Slovenia there is a very high at-risk-of-poverty rate among people aged 65 and over (21\% in 2008), and the rate is much higher than the at-risk-of-poverty rate in the total population $\left(12 \%\right.$ in 2008 [SURS 2010] $\left.^{1}\right)$. However, poverty measured by income is only one aspect of the deprivation and vulnerability faced by the elderly.

Given that Slovenia is a post-transition country its social welfare system has relatively recently undergone significant changes. The current system evolved out of the state-socialist welfare system established in Yugoslavia, with a welldeveloped and regionally dispersed network of public and state organisations and institutions [Kolarič 1992; Kolarič, Kopač and Rakar 2009]. The new welfare system that developed after the transition can be described as a 'welfare mix' and

\footnotetext{
${ }^{1}$ Data obtained from SURS—Statistični urad RS (Statistical Office of the RS). 2010. Statistični portal SI-STAT: Kazalniki dohodka in revščine [Indicators of Income and Poverty]. Retrieved 14 July 2010 (http://www.stat.si/pxweb/Database/Dem_soc/08_zivljenjska_ raven/08627_EU_SILC/08627_EU_SILC.asp).
} 
resembles the welfare systems of Western Europe, with some elements of a conservative-corporate welfare system (a compulsory social insurance system based on a social partnership) and a social-democratic welfare system, where a strong public or state sector is still the dominant service provider of all types of services, to which all citizens are equally entitled [Kolarič, Kopač and Rakar 2009]. However, some of the more generous parts of the social protection provided by the state have been slowly reined in [see Kopač 2005; Črnak Meglič 2005]. This means that in some areas government support for socially excluded groups, in our case the elderly, could be shrinking and this could potentially lead to their lower income and greater material deprivation.

Early retirement was an important characteristic of Slovenia in the early 1990s, when women could retire around the age of 52 and men around the age of 54 (for more details, see Hlebec, Filipovič Hrast and Kogovšek [2010]). The Pension and Disability Insurance Act [PDIA 1999], ${ }^{2}$ amended in subsequent years) abolished early retirement and set the fully pensionable retirement age at 63 for men and 61 for women and introduced 'penalties' for retiring early (lower pensions) and 'bonuses' for retiring after reaching the full retirement age. However, among those individuals who already took early retirement, their early retirement may have an indirect effect towards increasing their vulnerability as early retirement leads to lower monthly pensions owing to the low replacement and valuation rates.

Recent reforms have also seen the state withdraw from the provision of certain social services, causing the burden to shift to other sectors, mainly the private non-profit sector, voluntary organisations, and the family. The voluntary sector's importance has therefore been slowly growing since the transition and this might also be reflected in the sector's coming to assume a greater role in helping excluded the elderly.

The health-care system has continued to be relatively extensive and accessible. Basic (compulsory) health insurance (CHI) still covers almost the entire Slovenian population. Accordingly, access to basic health care is not expected to present a significant problem, even for more vulnerable groups. However, several services, such as medicines, require additional voluntary health insurance, so their accessibility is more limited. Long-term care is particularly important for preventing the social exclusion of the elderly. By long-term care we mean a complex set of social and health services that can be offered in either institutional or home settings and is provided by formal and/or informal actors. Available care services can range from assistance in independent living for the elderly to full-time nursing care (see, e.g., the description of housing with care settings in Evans [2009]). Such care in Slovenia is not uniformly organised or centrally co-

\footnotetext{
2 PDIA-Pension and Disability Insurance Act. 1999. Revised in 2005. Retrieved 26 December 2010 (http://www.uradnilist.si/_pdf/2005/Ur/u2005104.pdf ). The Act came into force on 1 January 2000.
} 
ordinated. As there is no integrated system, only within the framework of institutional assistance are health care and social care integrated, while assistance/care are not integrated in community care. Only $1.5 \%$ of the elderly population have ever used home help services [National Report on Strategies for Social Protection and Social Inclusion 2008: 72]. Long-term care services in Slovenia are therefore characterised by limited availability, geographical differences in the accessibility of these services [Smolej and Nagode 2008], high costs, and low quality due to a lack of co-ordination among different services and service providers. Consequently, care for the elderly has remained predominantly in the private, informal sector, and research has demonstrated the importance of the family in this regard [Hlebec, Filipovič Hrast and Kogovšek 2010; Hlebec 2009; Kogovšek et al. 2003; Jelenc Krašovec and Kump 2009].

\section{Methodology}

The research design used in our study includes the successive use of quantitative and qualitative methods [Creswell and Plano 2007]. We used an explanatory model with a participant selection variant that is based on a two-phase integrated research design, starting with the analysis of quantitative data followed by the collection and analysis of qualitative data with the objective of linking the qualitative and quantitative findings. The quantitative phase served as a starting point for establishing the share of the elderly population affected by various kinds of social exclusion and for the theoretical selection of participants for the qualitative part of the research on specific topics addressed in the qualitative phase.

In the qualitative part of the research we applied the grounded theory approach [Glaser and Strauss 1967] to study the inductively obtained strategies for coping with social exclusion. The grounded theory analysis is based on $32 \mathrm{in}$-depth interviews conducted with underprivileged older individuals. The in-depth interviews were arranged with groups of the elderly who were defined as excluded and vulnerable in the quantitative phase. The sample contains 26 women and 6 men between the ages of 58 and 90 (the average age was 78). With regard to their location, the interviewees were dispersed across urban and rural areas of Slovenia. The majority of interviewees owned their own flats, while six were tenants. The average monthly income of the interviewees was 502 EUR.

Our theoretical sampling was done in three stages. The primary selection of the first units was made on the basis of quantitative findings. The preliminary readings of the interviews showed that the dominant causes of social exclusion in everyday life relate to health problems and a lack of funds. Subsequent units were selected in two cycles according to these findings. We were assisted in finding suitable interviewees by two organisations that work with the elderly: within the Municipality of Ljubljana we cooperated with organisations providing home care services and we also received assistance from the Pensioners' Association, which operates nationwide. Since the analysis indicated that some differences 
also exist between the strategies of people living in different locations, we took that into account in the next stage of the sampling. ${ }^{3}$

The European Quality of Life Survey 2007 [EFILWC 2009] ${ }^{4}$ was not primarily designed to study social exclusion. We therefore designed several combined indicators of social exclusion in various areas based on theoretical definitions of social exclusion. The EQLS is a representative, questionnaire-based household survey series. The sample sizes of around 1000 per country (1035 for Slovenia) provide a general population profile, although they are too small to allow a detailed analysis of subgroups such as socially excluded elderly since the dimensions of social exclusion overlap (e.g. the number of widows without children living in rented flats would be very small).

Exclusion from the labour market and education are not included in the analysis in this article since only very few people in Slovenia are still economically active or included in education after age 65. The following indicators of social exclusion were observed: (1) Material deprivation-elderly people who could not afford at least three of the following were defined as materially deprived: adequate heating of one's residence; annual holidays; to change worn out furniture; a meal containing meat/chicken/fish at least every other day, if wanted; buying new instead of second-hand clothes; inviting family and friends for a drink or a meal at least once a month. (2) Housing-people were defined as experiencing housing exclusion if they had at least one of the following housing problems: a shortage of space; rot in the windows, doors or floors; damp or leaks in the walls or the roof; no indoor flush toilet; no bath or shower. (3) Health - self-rated health: people who rated their health as bad or very bad were defined as experiencing exclusion in the area of health. (4) Access to services and health care: Those who described their access to health care as very difficult for any of the following reasons: the distance to the doctor's office/hospital/medical centre; the length of time it takes to get an appointment; the length of time a person must wait to see a doctor on the day of an appointment; the cost of seeing a doctor. (5) The spatially excluded are those who do not have within walking distance at least two of the following in their neighbourhood: a grocery store or supermarket; a post office; banking facilities; public transport facilities. (6) Interpersonal relations-we defined the people who are excluded from this area as those who have no one to turn to in at least one of the following circumstances: needing help around the house when ill; needing advice about a serious personal or family matter; feeling depressed and wanting someone to talk to; urgently needing around 500/1000 EUR ${ }^{5}$ to deal with an emergency.

\footnotetext{
${ }^{3}$ Due to temporal and financial constraints, further theoretical sampling cycles were not conducted.

${ }^{4}$ EFILWC-European Foundation for the Improvement of Living and Working Conditions. 2009. European Quality of Life Survey 2007. UK Data Archive, Colchester, Essex.

${ }^{5}$ A smaller amount was used in the new member states.
} 


\section{Results of the quantitative analysis of social exclusion of the elderly}

What interests us in the quantitative part is which dimensions of social exclusion the elderly in Slovenia experience most. To this end, we compared older people with the total population and, for the illustrative purpose of placing Slovenia in the wider European context, we also compared the situation facing elderly Slovenians with the average findings for 'old members' of the European Union (EU15), all members of the European Union (EU-27), and the twelve new member states (NMS-12). The latter group chiefly includes 'transition countries' and could therefore have similar problems relating to the exclusion of the elderly.

In all of the observed areas of exclusion, except access to health care, statistical tests $\left(\chi^{2}\right)$ showed that the differences between the elderly and the rest of the population were significant.

\section{Material deprivation}

The elderly in Slovenia are materially much more deprived than the average in the population. This corresponds to the findings of research in both Slovenia and elsewhere on the greater financial and material vulnerability of the elderly and the higher at-risk-of-poverty rate of the elderly in Slovenia [see Stropnik and Kump 2008; Stropnik et al. 2010; Ogg 2005; SURS 2010]. Compared to the EU-15 average, the elderly in Slovenia are more deprived, although when compared to the NMS-12 average the situation of the elderly in Slovenia is much better, indicating a higher standard of living than can be found in the majority of 'posttransition' countries.

\section{Housing exclusion}

Just $21 \%$ of the elderly in Slovenia suffer from housing exclusion, which is less than the share in the population generally $(28 \%)$. Again, this is comparable to the EU-27 average, and it also reveals a much better picture than in the other new member states (NMS-12). The housing situation of the elderly is usually better than that of younger age groups, which corresponds to the housing careers of individuals [see, e.g., Mandič 2008]. Other research [Mandič 2010] has already shown the housing situation in Slovenia and other new member states to be worse than in older EU members, which is also reflected in our data.

\section{Health and access to services}

The $28 \%$ of the elderly in Slovenia who rate their health as poor is much higher than the average in the EU-15 (15\%) or the EU-27 (18\%), and more like that in 
other new member states. This might be related to poorer working conditions during the life course compared to Western European countries.

About one-third of the elderly have had difficulty accessing health services, which points to difficulties in the accessibility of health services. There are no agerelated differences in access to health care in Slovenia and it is comparable to the level of access observed in other new member states, which may reflect some similarities in post-transition countries. Health care is, however, less accessible than in the EU-15. The low accessibility of health services indicates that full coverage of the population with basic health insurance does not in itself mean full accessibility. Significant factors in this could be the way the health-care system is organised, long waiting lists/times for care, and the poor spatial accessibility of facilities.

\section{Spatial exclusion}

Perhaps the most problematic area of exclusion is the local environment, that is to say, spatial exclusion. Almost half the elderly in Slovenia do not have access to basic services in their local environment. This is higher than the population average (although even in the general population such access is poor), and is much higher than the averages for the EU-15, EU-27, and even the NMS-12, indicating that this is a feature specific to Slovenia and not linked to the (post)transition context. This exclusion is particularly problematic since the elderly comprise a population group that is less mobile and more dependent on the local environment, and, as research has shown, local mobility and the quality of neighbourhoods importantly affects the quality of life and the health of the elderly [Wight et al. 2007; Spinney, Scott and Newbold 2009]. The situation might have to do with Slovenia's geographic characteristics, its mountainous terrain and dispersed small settlements, and the absence of large urban regions with a high spatial concentration of services. Another factor might be the demise of small stores and their replacement with large shopping centres on the periphery of larger towns [Uršič 2003].

\section{Interpersonal relations}

The area where the share of the excluded is smallest is interpersonal inclusion. This shows that interpersonal relations in Slovenia are very good and people are connected by strong, supportive social networks. As indicated by other research [e.g. Hlebec, Filipovič Hrast and Kogovšek 2010; Pahor, Domajnko and Hlebec 2011], social support in Slovenia is strong and (especially for the elderly) strong family ties dominate. However, like other post-transition countries, Slovenia has often been found to have less social capital and social cohesion. Badescu and Uslaner [2003] described this as a residual effect of state repression, where people learned not to trust and which resulted in social networks being very small and limited to family and good friends. The good interpersonal connections indicated 
Table 1. Social exclusion of the elderly in Slovenia (\%)

\begin{tabular}{|c|c|c|c|c|c|c|c|c|}
\hline & \multicolumn{2}{|c|}{ Slovenia } & \multicolumn{2}{|c|}{ EU-15 } & \multicolumn{2}{|c|}{ NMS-12 } & \multicolumn{2}{|c|}{ EU-27 } \\
\hline & Total & $65+$ & Total & $65+$ & Total & $65+$ & Total & $65+$ \\
\hline Material deprivation & 10.2 & 18.9 & 10.1 & 11.1 & 36.5 & 60.3 & 15.7 & 20.2 \\
\hline Housing exclusion & 27.5 & 20.8 & 26.5 & 18.2 & 44.1 & 44.3 & 30.3 & 23.0 \\
\hline Poor health & 11.6 & 27.6 & 7.1 & 14.7 & 13.2 & 34.1 & 8.4 & 18.3 \\
\hline $\begin{array}{l}\text { Difficult access to health } \\
\text { services }\end{array}$ & 32.7 & 34.6 & 21.6 & 22.2 & 29.0 & 35.6 & 23.1 & 24.6 \\
\hline Spatial exclusion & 41.9 & 49.2 & 24.5 & 29.0 & 24.7 & 28.1 & 24.5 & 28.9 \\
\hline Interpersonal exclusion & 3.8 & 8.2 & 14.6 & 21.2 & 16.4 & 24.0 & 15.0 & 21.7 \\
\hline
\end{tabular}

Source: EFILWC [2009]; authors' calculations.

Table 2. Social exclusion of the elderly in Slovenia across age groups (\%)

\begin{tabular}{|c|c|c|c|c|c|c|c|c|c|}
\hline & \multicolumn{2}{|c|}{$18-64$} & \multicolumn{2}{|c|}{$65+$} & \multicolumn{2}{|c|}{ Total } & \multirow[t]{2}{*}{$\chi^{2}$} & \multirow[t]{2}{*}{$\mathrm{df}$} & \multirow[t]{2}{*}{ Sig. } \\
\hline & $N$ & $\%$ & $N$ & $\%$ & $N$ & $\%$ & & & \\
\hline Material deprivation & 68 & 8.1 & 37 & 18.9 & 105 & 10.2 & 20.111 & 1 & .000 \\
\hline Housing exclusion & 244 & 29.1 & 41 & 20.8 & 285 & 27.5 & 5.472 & 1 & .019 \\
\hline Poor health & 66 & 7.9 & 54 & 27.6 & 120 & 11.6 & 59.942 & 1 & .000 \\
\hline $\begin{array}{l}\text { Difficult access to } \\
\text { health services }\end{array}$ & 235 & 32.2 & 64 & 34.6 & 299 & 32.7 & 0.387 & 1 & .534 \\
\hline Spatial exclusion & 338 & 40.3 & 97 & 49.2 & 435 & 42.0 & 5.249 & 1 & .022 \\
\hline Interpersonal exclusion & 23 & 2.7 & 16 & 8.2 & 39 & 3.8 & 12.881 & 1 & .000 \\
\hline
\end{tabular}

Source: EFILWC [2009]; authors' calculations.

by our findings seem to imply that, even though networks are perhaps small, they are also strong and the majority of people do have someone to rely on (interpersonal exclusion was measured by having no one to rely on), who is most likely to be a close family member. This is also in line with the already indicated similarity between post-socialist countries and the familialistic southern European countries noted by Ogg [2005].

Based on the presented quantitative data, the areas of social exclusion of most significance for the elderly are those in which they are in a much worse position than the total population. The reason for this is that social exclusion is a relative concept, which implies observing situations and processes according to what is usual in a particular society, in our case Slovenia. An additional criterion 
is that a significant share of the population has to be affected (more than the average of the EU-27). The selection of the most important areas also provided a key to the theoretical sampling of participants in the qualitative phase of the study.

\section{Results of the qualitative analysis: coping with social exclusion}

Using qualitative methods we analysed how people experience and cope with social exclusion in the most pressing areas of exclusion as defined in the quantitative part, namely material deprivation and health and spatial exclusion.

Using a multistage qualitative coding procedure for the interviews several coping strategies were identified in every area, indicating that the elderly are not passive but are actively trying to improve their situation. Various studies support such findings in terms of older people's agency. The findings from five EU countries presented in Walker [2005] show that a significant share of the elderly engages in various social, cultural, and civic activities. In the study of coping strategies, the elderly are observed as active social actors and not passive dependant victims of the ageing process [Tanner 2007].

In-depth analysis shows that similar strategies are employed in the different areas of social exclusion observed (as indicated in the table below), while some strategies seem to be specific to a certain field. Such specific strategies are: work-

Table 3. Overview of strategies by areas of exclusion

\begin{tabular}{lccc}
\hline Strategy/Exclusion area & $\begin{array}{c}\text { Material } \\
\text { exclusion }\end{array}$ & Health & $\begin{array}{c}\text { Spatial } \\
\text { exclusion }\end{array}$ \\
\hline Working for resources & $*$ & $*$ & \\
Self-provision & $*$ & $*$ & \\
Careful management of resources & $*$ & $*$ & $*$ \\
Cohabitation & $*$ & $*$ & $*$ \\
Limiting expenses & $*$ & $*$ & \\
Using past savings & $*$ & $*$ & $*$ \\
Use of social networks & $*$ & $*$ & $*$ \\
Use of formal services & $*$ & $*$ & \\
Careful nutrition & $*$ & & \\
Avoidance (of thinking about the future) & & & \\
Limiting certain behaviours & & & \\
Home modification & & & \\
\hline
\end{tabular}

Source: Qualitative data gathered by the authors. 
ing, self-provision and management of resources. The majority of strategies are such that they are not specific to a certain area. The most general are the use of social networks and limiting certain behaviour, which are strategies found in all three exclusion areas we observed.

The use of formal resources was found in two but not all three areas observed, which is surprising since we expected to find this strategy in every area of exclusion. This might to some extent have to do with the mode of participant selection (as we used a formal health service to select some of the participants), but it might also have to do with less awareness among the elderly about other formal assistance services. However, the absence of formal strategies relating to material exclusion, where services and financial aid are supplied by the state, calls for further research. Below, coping strategies are presented in detail in each of the three areas.

\section{Material deprivation}

As the interviews suggest, the strategies that the elderly employ to cope with material deprivation are numerous and are often used in various combinations. However, there are also limitations on which strategies can be used. Working for additional income is a strategy mainly used by people who are healthy enough still to do some work and also have skills from their working careers that can be harnessed (e.g. dressmaker, house painter). Older people do some small jobs in exchange for either money or payment in kind. As Schroder-Butterfill and Marianti [2006] claim, people's vulnerabilities are the result of their life histories, with past outcomes determining present exposure and coping, and our study confirms this.

Igor, age 78: I: You worked until last year ... ? What did you do? R: You know, painting ... decorating! I can still do it . . no sweat . . . up the ladder . . . I: Did you do this in order to make ends meet? R: Yes, well, you know, to get a little extra, isn't it?! [laughs]

Self-provision is also an important strategy, as people reduce their food costs this way. It is a strategy most often found in rural areas where people have their own gardens. The limitations on this strategy are the health of the elderly

In addition, the elderly manage their food consumption very carefully, cooking larger amounts of food and then eating it throughout the week, or buying seasonal food when it is cheaper and storing it for later, or carefully seeking out the best prices.

Tatjana, age 90: R: I am not one to throw food away, some throw bits and pieces away, but this container is worth its weight in gold. I don't do this, I cook, I ask for, let's say, 1 kilogram of cabbage to be brought to me, and I cook it all and then I put some 
aside and the rest I store in small boxes and put in the freezer, and I have cabbage, barley, turnip, the salad I make fresh, I buy potatoes in autumn, so I can cook them whenever, and so on.

One of the most common strategies used is to limit expenses and, relatedly, behavioural changes. Spending cutbacks involve either the money spent on food (e.g. sweets, meat) or clothing purchases, while the behavioural changes mainly involve curtailing hobbies or travel. Such things are often seen as luxuries that are not truly needed. The elderly also limit their expenses on vital things like heating or food. These limitations were often not regarded as problematic, but rather as a normal part of the person's life history (they had constantly had to accept such limitations in life) or a normal part of ageing and changing needs. People therefore adjust their goals and expectations in response to change (old age) [SchroderButterfill and Marianti 2006].

Tatjana, age 90: R: I try to save, but I was never hungry, I don't mind what I eat. Sometimes I have a good appetite, that's when I would like to eat more. Well, but it just can't be done. I: Do you not have enough at home? R: No, I haven't got enough at home, and then I have to go and buy some, but it's just too expensive . . . but I only take this, I take that, and yoghurt and so on to go with it, I buy that, and cottage cheese, things that are healthy, and I grew up on polenta and potatoes and cabbage, so that's good enough for me now.

Drawing on their savings is a strategy that the elderly employ to finance either their current needs or larger (unexpected) expenses like repairs or new household appliances. Of course, this strategy depends on the individual's life history and whether an individual or the family (usually a partner) was able to save money in the past.

Helena, age 72: R: We usually run out every month and then I try to make ends meet with the money we have saved . . . but the amount is becoming ever smaller and I am terrified to think what will happen when it disappears . . . and it will not be long now.

Another important element of coping strategies is the help that the elderly receive from their social networks - help from family members (those not living in the household) is vital, but also from the community, either neighbours or voluntary associations. Voluntary associations help financially or in kind, while neighbours mainly help in kind. For those older people who live with other family members (cohabitation), sharing expenses is an important strategy for coping with material deprivation.

Another strategy is simply to avoid thinking about the future. The elderly in particular do not want to think about future material deprivation and mainly plan from day to day. 
Katja, age 83: I: Aren't you interested about anything regarding the future, you don't think about that? R: Why should I think about that, how could I? I: Maybe you could arrange some sort of home help for the future? To get some nurses to come to your home? R: My pension is too small to pay for a nurse. I don't have enough.

We interpret this avoidance as being a result of the stress and sorrow that such planning brings. If there is nothing that can be done to overcome adverse future development, accepting or ignoring what cannot be controlled may be an effective approach [Lazarus and Folkman 1984: 137, 140]. This is supported by Soerensen and Pinquart [2000: 376], who reported that a lack of financial or social resources inhibits planning for future care.

\section{Health}

The elderly have limited mobility due to their health and receive help from members of their social networks (friends, neighbours, family) who aid them in their everyday lives (e.g. going to the shop, cooking, washing clothes).

Monika, age 61: I: That's what I thought, who helps you with these things. Who goes to the shop, and ... R: My neighbour. As I said she brings the things, 'cause I can't get my tights on. 'Cause my hip hurts so much that I have to ....

In some cases, community help is unavailable or the older people do not wish to burden their informal social network. Consequently, they rely on formal services. Yet this is very difficult for financially deprived older people and may necessitate the use of several coping strategies to deal with the financial strain.

For those elderly living with family members, an important strategy is to share the work and do those things their health allows them to do, while other family members do the things they can no longer perform.

Polona, age 84: I: How do you usually help each other? Respondent's son: You know how it is. R: I can't do anything outdoors. Respondent's son: She takes care of the household. R: I cook and so forth. Respondent's son: Transport, and the shops and stuff, that's mine, mainly I pick up things. And the little one helps with the work, and clears up sometimes. Outdoors in our garden, we take care of the garden together.

In the area of health people also try to limit their expenses, even if the consequence might be poorer health or a poorer quality of life. For example, they limit their expenditures on medicines or medical accessories. On the other hand, they may also draw on their savings to finance these needs. Both strategies have negative consequences; the first for the health of the individual, while the second potentially leads to the depletion of resources and material deprivation and/or the 
use of other strategies, such as limiting expenses and therefore even poorer health. Another strategy is careful nutrition. This is also linked to limiting expenses on food types (as mentioned in the section on material deprivation), which however they also justify as being more healthy for them.

Nada, age 76: R: Well, I had to give up certain foods. That I had to do. And some, and some expensive medications.

Zala, age 76: R: I had to pay three hundred for an earpiece and for my glasses I had to pay ... hmmm ... two hundred . . . but the lenses for the frame I had . . . and er ... teeth, I gave six hundred euros for them. I: You seem to have quite a few expenses? $R$ : If you do not have any savings, to draw on, then you can't get anything.

They are also aware of their more fragile state and value their good health and the independence that brings. They are consequently always aware of this fact and try to avoid 'risky' behaviour or 'risky' chores, and they are constantly vigilant when moving around the house, working, and doing everyday chores, so as not to fall and hurt themselves.

Katja, age 83: R: And then I write things down, don't I? Like this. I: Er, what if you were boiling water or something else on the cooker, would you forget to turn it off? R: I go and check the cooker in the evening before I go to sleep [laughs] ... and sometimes I go and check it again, and that is when I say that I am checking up on it, isn't that right?

In connection with the above, the elderly also try to make modifications to their homes to better serve their changed health status. If they have sufficient funds, many try to adapt or renovate their homes. In most cases they renovate bathrooms, install handles or handrails on the staircases, or install assistive technologies, aids and other accessories that prevent accidents and injuries. These include walking aids (canes, crutches, walkers), wheelchairs, hearing and optical aids, different types of alarms and telecare (e.g. 'the red button').

Avoidance thinking relating to health is another very prominent mental coping strategy that we found. The elderly are reluctant to think about their future health and often avoid planning for their future (health) needs. They are worried about what their deteriorating health will mean for their independence and for their family. However, no solutions linked to this were identified.

\section{Spatial exclusion}

Spatial exclusion is linked to poor access to basic services in the local environment (such as banks, supermarkets, post offices) and to problems of mobility. As not all services are available in the immediate vicinity of a person's residence, 
finding transport to these services is essential for the elderly. The main strategy for dealing with spatial exclusion is obtaining help from social networks. Family networks predominate here. Social network members offer transport to necessary services (e.g. visiting a doctor) or they bring things that are needed (e.g. groceries). It is interesting that the elderly very often offer token financial compensation for these services (to their children or grandchildren), even if it is unnecessary. This financial compensation seems to be a way in which the elderly try to compensate for burdening their networks and to maintain reciprocal relations.

Janja, age 81: R: Well, they come so that they can drive me somewhere, in this sense I am dependent on my children, as long as I have them I will not ask anybody else.

The elderly also receive help from formal services. However, this strategy is usually employed when they need other forms of help (for health reasons) and therefore these services are not exclusively used for dealing with spatial exclusion (e.g. a nurse who also goes to the shop for them).

Spatial exclusion can be alleviated by some formal banking arrangements and services and the use of some assistive technologies (e.g. telecare or 'the red button'). Home modification can also be regarded as a strategy for mitigating spatial isolation. Handrails, ramps for wheelchairs, and the like, facilitate basic spatial mobility and primarily offer a way out of the home.

The last strategy is to limit certain behaviours, for instance, by not using local services due to poor accessibility. This strategy of course is not used in the case of the most vital services (where other strategies are used), but it does apply to the use of services or events in the community that the elderly would perhaps use if they were more accessible. Examples of such services include the theatre, cinema, and music events.

\section{Summary and discussion of the qualitative findings}

Above we described the strategies that we observed in different exclusion areas. We have not specifically grouped the presented strategies, although we can apply the classification of strategies by Schroder-Butterfill and Marianti [2006], who describe the main coping capacities of the elderly as: individual capacities (wealth, human capital), social networks, and formal social protection. Somewhat similar is the classification by Monroe et al. [2007]. They distinguish between internal, external, and government-supported strategies. If we apply these classifications, it is evident that the majority of strategies we found are internal or individual (e.g. limiting expenses, careful nutrition, using one's savings). Also important in all three observed areas are external strategies or social networks. Governmentsupported strategies or formal social protection are more difficult to define in our case and are the least numerous in our study. This could reflect the lack of 
government support in Slovenia as a result of the (post)transition context and the slow transformation of the welfare state.

Another specific feature of Slovenia is the very strong use of support networks, something also found in social network research [Hlebec, Filipovič Hrast and Kogovšek 2010; Pahor, Domajnko and Hlebec 2011]. The relevance of social networks was evident in all of the observed areas of exclusion. However, this also means that not having these networks can significantly increase the degree to which the elderly are excluded. The existence of strong family networks may be connected to the transitional context, as Badescu and Uslaner [2003] claim. Kolarič et al. [2009] also found that in Slovenia, even before the transition, the insufficient provision of formal services was complemented by the provision of intensive informal (mainly family) support, which is similar to Tchernina and Tchernin's [2002] observations for Russia. However, this might also be the result of the existence of historically strong and complex family structures [see Hank 2007] and reflects a similarity with the familialistic characteristics of Slovenia's neighbour Italy and other southern European countries.

In the area of spatial exclusion, the number of strategies employed was significantly less than in the two other observed areas (health and material deprivation), thus indicating the difficulty the elderly have coping in this area. Spatial exclusion does not seem to be tied to the post-transition context, as the quantitative data did not indicate similar problems in other new member states. To some extent it can be ascribes to the specific geographical characteristics of Slovenia (mountainous terrain, dispersed settlements). However, these issues certainly call for further research.

The material deprivation of the elderly, on the other hand, can be linked to the post-transition context. In particular, the low pensions in this region (early retirement combined with small increases in pensions) coupled with the slow withdrawal of the state from its supportive functions may be important factors influencing the substantial material deprivation of the elderly and the above-noted dependency on an individual's own capacities and personal social networks.

\section{Discussion and conclusion}

We found that studying coping strategies is a very useful tool for understanding social exclusion. The numerous strategies that the elderly apply are indicative of their resourcefulness. Even though quantitative data may indicate that someone is poor, when the person's quality of life is observed using qualitative methods we can find that their quality of life is not really poor (owing, potentially, to potentially good social networks, family aid, savings, etc.). And the same is true, of course, the other way around, so that even though quantitative data may indicate that someone does not belong to a vulnerable group (e.g. has relatively good income), qualitative methods may point to poor quality of life. However, the coping 
strategies we found in the interviews also indicated that the majority of strategies lead only to a reduction of exclusion in a certain area. The methodological limitations make it hard to draw conclusions on how permanent the exclusion is for older people. However, our results seem to indicate that, even though social exclusion is dynamic in nature, the elderly have few ways of exiting it, which is in line with what Scharf, Phillipson and Smith [2005] have argued. For example, the use of one's personal savings only temporarily means a reduction of financial deprivation and cannot be seen as an exit strategy. Many of the strategies we observed therefore often seem to lead towards the depletion of resources (financial, personal, or other) and in the long run might even indicate a future worsening of the person's situation. These processes need to be further researched. The qualitative analysis of social exclusion through coping strategies seems to be a good way of researching the dynamic nature of the concept, the nature of the barriers of social exclusion, and the links between different areas of exclusion.

Are the coping strategies of the elderly the same as the coping strategies adopted by other vulnerable groups in similar circumstances? One could say there is a certain level of generalisability, although coping strategies also reflect and depend on past experiences, skills, knowledge, and values. The elderly as a cohort have lived through serious deprivation and war and may therefore have different values and are perhaps more inclined/disposed to adjusting their lifestyle to scant resources. As mentioned, many of the coping strategies were not perceived as strategies for coping with problems, but as a normal part of everyday life. As Schroder-Butterfill and Marianti [2006: 15] note, people adjust their goals and priorities in response to change, for example the expectation of poorer health or a lower standard of living. As our research demonstrates, the strategies were often part of a changing 'lifestyle' due to age, or part of normal lifestyle limitations that already characterised people's lives in the past. In addition, it is also evident that the elderly often employed the 'downward contrast' strategy [Beaumont and Kenealy 2004]. This means that they compared themselves with others who are even worse off or who have even fewer possibilities and strategies for coping with their exclusion, and they consequently did not perceive their situation as problematic.

What we have not specifically addressed in our analysis is the differences in coping strategies that might potentially be due to individual or contextual reasons. For example, Sherman [2006] advocates an important difference between rural and urban coping strategies, which have also been noted by Tchernina and Tchernin [2002]. The community a person lives in influences the opportunities for survival and affects the significance of the available strategies. These differences were also partly detected in our research as some strategies were only available in rural areas (such as self-provision). However, our sample does not allow us to research these differences in any greater detail, leaving this as a future avenue for research.

The specifics of Slovenia and its post-transition context are difficult to discern due to the study's limitations. The quantitative research indicated the most 
important areas of exclusion, namely material deprivation and health and spatial exclusion. These were the areas where the circumstances of the elderly were significantly worse than those of the rest of the population, and were also worse than the circumstances facing the elderly in the majority of other European Union member states (in comparison to the average). Moreover, the group of new member states showed that in all of these areas the shares of the elderly experiencing deprivation are higher than in the rest of the EU.

The majority of coping strategies we found involved the use of individual resources and social networks, whereas formal or government-supported strategies were very rare. However, individual capacities are rarely sufficient to cope with the challenges of old age, while relational resources or links to formal resources are usually more effective [Schroder-Butterfill and Marianti 2006]. Tchernina and Tchernin [2002], for instance, report that in Russia the principle of solidarity and intergenerational support represents the main source of the elderly's welfare. A small number of government-supported strategies could be a particularity of societies in transition (such as Slovenia) since the welfare system is still developing, so the government perhaps still offers less support to vulnerable groups than other 'old member states'. Ogg [2005] similarly argues that the social exclusion of the elderly in post-socialist countries is greater due to their still developing social welfare systems.

Cohabitation with other family members is another strategy specific to post-transition societies. Hank [2007] claims that in eastern and southeast Europe complex family forms within a single household are historically typical, including three-generation families (which are even more common than in southern Europe). The use of cohabitation as a strategy (to cut costs or compensate for poor health) might potentially be found less often in other countries, in particular in Scandinavian countries, where it is more common for the elderly to live independently and where they much more rarely cohabit with their children [see Hank 2007].

The mentioned lack of formal social protection strategies and strong reliance on the family (the use of social networks, cohabitation) does not mean that various policies for reducing the elderly's social exclusion in Slovenia simply do not exist. They do, and they are mainly directed at the areas of material and financial deprivation. Here the pension system and the social welfare system are crucial. Yet the limitations on pensions and the noted limitations in the area of social protection will further exacerbate the exclusion of the elderly. Furthermore, our research indicates that the development of (accessible) home care services is greatly needed to prevent the social exclusion of the elderly and, in particular, it could improve spatial inclusion.

Policies not often perceived as vital for increasing social inclusion are urban and spatial policies, which, in the case of Slovenia, seem to be the most needed since spatial exclusion has been identified as a concern of a large share of the elderly and is also an area where they have developed the fewest coping strategies. However, when formulating policies to aid the elderly and prevent exclusion, it 
is necessary to carefully take into account people's different priorities. Living in an environment with few services and consequently in a state of spatial exclusion can in some cases also be a choice individuals make in order to keep their spatial and personal identity and maintain social networks established in that place, which might also be vital for preventing social exclusion in other areas.

Lastly, we would also like to address some methodological issues. While there are clearly many advantages to using secondary quantitative data, such as saving time and money on developing indicators, designing a quantitative study, and collecting, storing and cleaning the data, there are also several disadvantages to secondary data analysis, such as the content validity of indicators and small sample size [Hlebec and Kogovšek 2005; Hlebec, Šircelj and Mrzel 2010; Hlebec, Mrzel and Kogovšek 2011] in general, and some shortcomings specifically arising from the selected mixed-methods model [Hlebec 2009]. One of these is the time gap (the EQLS data were collected in 2007, whereas the interviews were conducted in 2009). We assume that the time gap was not too big and that the same dimensions of social exclusion that were the most important in 2009 were also the most important in 2007 and the same basic groups of participants were the most vulnerable. Research on social exclusion in Slovenia and elsewhere shows that vulnerabilities and excluded groups are quite stable over time [Trbanc 1996; Muffels, Tsakloglou and Mayes 2002].

MašA FILIPOVIČ Hrast is an assistant professor at the Faculty of Social Sciences of the University of Ljubljana. As a researcher she has participated in national and European projects related to the following themes: social exclusion and poverty, vulnerable groups (elderly, homeless), social cohesion, neighbourhood and community life, and intergenerational solidarity.

VALENTINA HLEBeC is a professor of sociology at the Faculty of Social Sciences of the University of Ljubljana. Her research interests include sociology of ageing, social networks, and survey methodology, in particular designing and testing survey questionnaires. She has participated in several national and international projects in these fields.

Matic KaVČrč received his PhD in sociology from the University of Ljubljana in 2011 and is currently working as a researcher and teaching assistant at the Faculty of Social Sciences and the Faculty of Health Sciences there. His main research interests include the quality of life of the elderly, risks and social support networks of the elderly, and methodological issues pertaining to qualitative and mixed-method research techniques. 


\section{References}

Atkinson, T., B. Cantillon, E. Marlier and B. Nolan. 2002. Social Indicators. The EU and Social Inclusion. Oxford: Oxford University Press.

Badescu, G. and E. Uslaner. 2003. Social Capital and the Transition to Democracy. London and New York: Routledge.

Bajekal, M., D. Blane, I. Grewal, S. Karlsen and J. Nazroo. 2004. 'Ethnic Differences in Influences on Quality of Life at Older Ages: Quantitative Analysis.' Ageing and Society 24 (5): 709-728.

Beaumont, J. G. and P. M. Kenealy. 2004. 'Quality of Life Perceptions and Social Comparisons in Healthy Old Age.' Ageing and Society 24 (5): 755-769.

Creswell, J. W. and C. V. L. Plano. 2007. Designing and Conducting Mixed Methods Research. Thousand Oaks, CA: Sage.

Črnak Meglič, A. 2005. Otroci in mladi v prehodni družbi. (Children and Youth in Society in Transition) Ljubljana: Urad za mladino.

Dalstra, J. A. A., A. E. Kunst and J. P. Mackenbach. 2006. 'A Comparative Appraisal of the Relationship of Education, Income and Housing Tenure with Less Than Good Health among the Elderly in Europe.' Social Science and Medicine 62 (8): 2046-2060.

European Commission. 2008. Demography Report 2008: Meeting Social Needs in an Ageing Society. SEC [2008] 2911. Brussels: European Commission. Retrieved 26 October 2012 (http://ec.europa.eu/social/BlobServlet?docId=709\&langId=en).

Evans, S. 2009. Community and Ageing: Maintaining Quality of Life in Housing with Care Settings. Bristol: Policy Press.

Gabriel, Z. and A. Bowling. 2004. 'Quality of Life from the Perspectives of Older People.' Ageing and Society 24 (5): 675-691.

Glaser, B. G. and A. L. Strauss. 1967. The Discovery of Grounded Theory: Strategies for Qualitative Research. Chicago, IL: Aldine Publishing Company.

Hank, K. 2007. 'Proximity and Contacts between Older Parents and Their Children: A European Comparison.' Journal of Marriage and Family 69 (1): 157-173.

Hlebec, V. (ed.) 2009. Starejši ljudje v družbi sprememb. (The Elderly in a Changing Society) Maribor: Aristej.

Hlebec, V. and T. Kogovšek. 2005. 'Med korenčkom in palico sekundarne analize podatkov o socialnih omrežjih.' (Caught between the Advantages and Disadvantages of Secondary Data in Social Network Analysis) Družboslovne Razprave 49/

50 (21): 189-203. Retrieved 27 October 2012 (http://dk.fdv.uni-lj.si/dr/dr4950HlebecKogovsek.PDF).

Hlebec, V., M. Filipovič Hrast and T. Kogovšek. 2010. 'Social Networks in Slovenia.' European Societies 12 (5): 697-717.

Hlebec, V., M. Šircelj and M. Mrzel. 2010. ‘How to Monitor Intergenerational Solidarity in Social Support Networks?' Teorija and praksa 47 (6): 1127-1149.

Hlebec, V., M. Mrzel and T. Kogovšek. 2011. 'Assessing Social Support Networks in Cross-National Comparative Surveys: Measurement Issues.' Quality and Quantity 46 (5): 1431-1449. Retrieved 30 May 2011 (http://www.springerlink.com/content/ rm55604783838587/fulltext.pdf, doi: 10.1007/s11135-011-9456-7).

Jelenc Krašovec, S. and S. Kump. 2009. 'Adult Learning Activities, Social Networks and Different Neighbourhoods.' European Societies 11 (2): 257-282.

Kogovšek, T., V. Hlebec, P. Dremelj and A. Ferligoj. 2003. 'Omrežja socialne opore Ljubljančanov.' (Social Support Networks of Ljubljana Residents) Družboslovne razprave 19 (43): 183-204.

Kolarič, Z. 1992. 'From Socialist to Post-Socialist Social Policy.' Pp. 15-32 Social Policy in Slovenia, edited by I. Svetnik. Avebury: Ashgate. 
Kolarič, Z., A. Kopač and T. Rakar. 2009. 'The Slovene Welfare System: Gradual Reform instead of Shock Treatment.' Pp. 444-461 in The Handbook of European Welfare Systems, edited by K. Schubert, S. Hegelich and U. Bazant. London and New York: Routledge.

Kopač, A. 2005. ‘Od brezpogojne k pogojevani državi blaginje-spremembe znotraj koncepta državljanstva.' (From Unconditional to Conditioned Welfare State-Changes in the Citizenship Concept) Družboslovne razprave 21 (49/50): 51-64.

Langille-Hoppe, M., J. Gonzales, M. Maxey and S. Terrel. 2010. 'What Makes You Think I'm Poor? A Qualitative Analysis of Etic and Emic Perceptions of Poverty in the Ozarks.' Journal of Ethnographic and Qualitative Research 4 (3): 125-138.

Layte, R., B. Maitre and C. Whelan. 2010. Second European Quality of Life Survey: Living Conditions, Social Exclusion and Mental Well-Being. Dublin: European Foundation for the Improvement of Living and Working Conditions.

Lazarus, R. S. and S. Folkman. 1984. Stress, Appraisal, and Coping. New York: Springer Publishing Company.

Mandič, S. 2008. 'Home-Leaving and Its Structural Determinants in Western and Eastern Europe: An Exploratory Study.' Housing Studies 23 (4): 615-636.

Mandič, S. 2010. 'The Changing Role of Housing Assets in Post-Socialist Countries.' Journal of Housing and the Built Environment 25 (2): 213-226.

Mayes, D. G., J. Berghman and R. Salais. 2001. Social Exclusion and European Policy: Globalisation and Welfare. Cheltenham, Northampton: Edward Elgar.

Monroe, P., V. R. Tiller, C. E. O'Neil and L. L. Blalock. 2007. 'We Make Our Ends Meet Good: Coping Strategies of Former Welfare Reliant Women.' Journal of Loss and Trauma 12 (3): 199-221.

Moriarty, J. and J. Butt. 2004. 'Inequalities in Quality of Life among Older People from Different Ethnic Groups.' Ageing and Society 24 (5): 729-753.

Muffels, R. J. A. and D. Fourage. 2001. 'Social Exclusion and Poverty: Definition, Public Debate and Empirical Evidence in the Netherlands.' Pp. 93-124 in Social Exclusion and European Policy: Globalisation and Welfare, edited by D. G. Mayes, J. Berghman and R. Salais. Cheltenham, Northampton: Edward Elgar.

Muffels, R. J. A. and D. Fourage. 2002. 'Do European Welfare Regimes Matter in Explaining Social Exclusion?' Pp. 202-235 in Social Exclusion in European Welfare States, edited by R. J. A. Muffels, P. Tsakloglou and D. G. Mayers. Cheltenham, Northampton: Edward Elgar.

Muffels, R. J. A., P. Tsakloglou and D. G. Mayes. 2002. Social Exclusion in European Welfare States. Cheltenham, Northampton: Edward Elgar.

National Report on Strategies for Social Protection and Social Inclusion 2008-2010. 2008. Ljubljana: Ministry of Labour, Family and Social Affairs. Retrieved 26 October 2012 (http://www.mddsz.gov.si/fileadmin/mddsz.gov.si/pageuploads/dokumenti_pdf/ npsszsv08_10.pdf).

Ogg, J. 2005. 'Social Exclusion and Insecurity among Older Europeans: The Influence of Welfare Regimes.' Ageing and Society 25 (1): 69-90.

Pahor, M., B. Domajnko and V. Hlebec. 2011. 'Social Support in the Case of Illness: Intergenerational Solidarity.' Zdravniški Vestnik 80 (2): 75-83.

Raveaud, G. and R. Salais. 2001. 'Fighting against Social Exclusion in a European Knowledge Based Society: What Principles of Action.' Pp. 47-72 in Social Exclusion and European Policy: Globalisation and Welfare, edited by D. G. Mayes, J. Berghman and R. Salais. Cheltenham, Northampton: Edward Elgar.

Room, G. 1995. Beyond the Threshold: The Measurements and Analysis of Social Exclusion. Bristol: The Policy Press.

Scharf, T., C. Phillipson, A. Smith and P. Kingston. 2003. Older People in Deprived Neighbourhoods: Social Exclusion and Quality of Life in Old Age. Full Report of 
Research Activities and Results. Growing Older Programme. Sheffield: University of Sheffield.

Scharf, T., C. Phillipson and A. E. Smith. 2005. 'Social Exclusion of Older People in Deprived Urban Communities.' European Journal of Ageing 2 (2): 76-87.

Schroder-Butterfill, E. and R. Marianti. 2006. 'A Framework for Understanding Old-Age Vulnerabilities.' Ageing and Society 26 (1): 9-35.

Sen, A. 2000. 'Social Exclusion: Concept, Application, and Scrutiny.' Social Development Papers No. 1. Manila: Asian Development Bank, Office of Environment and Social Development. Retrieved 15 July 2005 (http://wwww.adb.org/Documents/Books / Social_Exclusion/Social_Exclusion.pdf).

Sherman, J. 2006. 'Coping with Rural Poverty: Economic Survival and Moral Capital in Rural America.' Social Forces 85 (2): 891-913.

Siegrist, J. 2000. 'Place, Social Exchange and Health: Proposed Sociological Framework.' Social Science and Medicine 51 (9): 1283-1293.

Simms, M. 2004. 'A Theory of Age Exclusion through Closure: Chronological Aid to Clinical Need.' Journal of Ageing Studies 18 (4): 445-465.

Smith, A. E., J. Sim, T. Scharf and C. Phillipson. 2004. 'Determinants of Quality of Life amongst Older People in Deprived Neighbourhoods.' Ageing and Society 24 (5): 793-811.

Smolej, S. and M. Nagode. 2008. Spremljanje izvajanja programov socialnega varstva: končno poročilo. (Implementation of Social Protection Programmes-Final Report) Ljubljana: Inštitut Republike Slovenije za socialno varstvo.

Soerensen, S. and M. Pinquart. 2000. ‘Preparation for Future Care Needs: Styles of Preparation Used by Older Eastern German, United States, and Canadian Women.' Journal of Cross-Cultural Gerontology 15: 349-381.

Spinney, J. E. L., D. M. Scott and B. K. Newbold. 2009. ‘Transport Mobility Benefits and Quality of Life: A Time-Use Perspective of Elderly Canadians.' Transport Policy 16 (1): 1-11.

Stropnik, N. and N. Kump. 2008. 'Income and Poverty among the Older People in the New Member States: A Cross-Comparative Analysis.' Pp. 3-43 in The Elderly Poor in the EU's New Member States, edited by J. C. Vrooman. Brussels: European Network of European Policy Research Institutes.

Stropnik, N., N. Kump, M. Filipovič Hrast, V. Hlebec, A. Vezovnik and M. Kavčič. 2010. Revščina in materialna deprivacija starejšega prebivalstva: Projekt v okviru CRP Konkurenčnost Slovenije 2006-2013 v letu 2006. (Poverty and Material Deprivation of the Elderly. Project carried out within CRP competitveness of Slovenia) Ljubljana: Inštitut za ekonomska raziskovanja. Retrieved 14 July 2010 (http://www.mddsz.gov. si/fileadmin/mddsz.gov.si/pageuploads/dokumenti_pdf/revscina_IER.pdf).

Tanner, D. 2007. 'Starting with Lives: Supporting Older People's Strategies and Ways of Coping.' Journal of Social Work 7 (1): 7-30.

Tchernina, V. N. and A. E. Tchernin. 2002. ‘Older People in Russia's Transitional Society: Multiple Deprivation and Coping Responses.' Ageing and Society 22 (5): 543-562.

Trbanc, M. 1996. 'Social Exclusion: The Concept and Data Indicating Exclusion in Slovenia.' Družboslovne Razprave 12 (22/23): 99-114.

Tsakloglou, P. and F. Papadopoulos. 2002. 'Identifying Population Groups at High Risk of Social Exclusion: Evidence from the ECHP.' Pp. 135-169 in Social Exclusion in European Welfare States, edited by R. J. A. Muffels, P. Tsakloglou and D. G. Mayes. Cheltenham, Northampton: Edward Elgar.

Uršič, M. 2003. Urbani prostori potrošnje. (Urban Spaces of Consumption) Ljubljana: Fakulteta za družbene vede. 
Vleminckx, K. and J. Berghman. 2001. 'Social Exclusion and the Welfare State: An Overview of Conceptual Issues and Implications.' Pp. 27-46 in Social Exclusion and European Policy. Globalisation and Welfare, edited by D. G. Mayers, J. Berghman and R. Salais. Cheltenham, Northampton: Edward Elgar.

Walker, A. 2004. 'The ESRC Growing Older Research Programme.' Ageing and Society 24 (5): 657-674.

Walker, A. (ed.) 2005. Growing Older in Europe. New York: Open University Press.

Wight, R., J. R. Cummings, D. Miller-Martinez, A. S. Karlamangla, T. E. Seeman and C. S. Aneshensel. 2007. 'A Multilevel Analysis of Urban Neighborhood Socioeconomic Disadvantage and Health in Late Life.' Social Science and Medicine 66 (4): 862-872. 